\author{
cumhuriyet ilahigat dergisi 20, sy. 1 (Haziran 2016): 203-224 \\ cumhuriget theology journal 20, no. ( (June 2016): 203-224 \\ \& Hakemli Araşturma Makalesi / Peer-reviewed Research Article \&
}

\title{
Son Dönem Bir Osmanlı Düşünürü: Harputlu İshak Efendi'nin Din Felsefesinin Bazı Meselelerine Yaklaşımı ve Felsefecilere Karşı Tutumu
}

A Thinker of the Late Ottoman: Harputlu Ishak Efendi's Approaching to Some Issues of Philosophy of Religion and Attitude to Philosophers

Tuncay Akgün*

\section{ÖZ}

Osmanlı düşünürlerinin ya da âlimlerinin genelde felsefeye özelde din felsefesinin konularına ve felsefecilere bakışı ne idi? Osmanlı'da felsefenin diğer ilimlere nispetle varlığ 1 ve seviyesi ne durumda idi? gibi sorular

\section{ABSTRACT}

What was the point of view of the Ottoman thinkers or scholars in general to philosophy and in particular to subjects of the philosophy of religion and to philosophers? In Ottoman, what was the existence and level of

\footnotetext{
Yrd. Doç. Dr., İnönü Üniversitesi, İlahiyat Fakültesi, Felsefe ve Din Bilimleri Bölümü, Din Felsefesi Anabilim Dal.

Assistant Professor, University of Inonu, Faculty of Divinity, Department of Philosophy and Religious, Philosophy of Religion. Malatya/Turkey (tuncay.akgun@inonu.edu.tr)

- Bu makale araştırmacı tarafından Uluslararası Harput'a Değer Katan Şahsiyetler Sempozyumu'nda sözlü olarak sunulan ve basılmayan "Harputlu İshak Efendi'nin Felsefeye ve Felsefecilere Karşı Tutumu" adlı tebliğin içeriği geliştirilerek ve kısmen değiştirelerek üretilmiş halidir.

- cumhuriget ilahigat dergisi'nde yayımlanan makaleler, en az iki hakem tarafından çift taraflı kör hakemlik değerlendirmesine tabi tutulur. Ayrica intihal içermediği özel bir yazılım kullanılarak kontrol edilir.
- This paper is the final version of an earlier announcement called "Attitudes of Ishak Efendi of Harput Towards Philosophers", not previously printed, but orally presen- ted at an international Symposium called "The Figures Contributing to Harput", the content of which has now been deve- loped and partially changed.
- cumhuriget theology journal uses double-blind review fulfilled by at least two reviewers. In addition, all articles are chec- ked by means of a program in order to con- firm they are not published before and av- oid plagiarism.


felsefe ile uğraşanların sıkça sorduklar1 sorular olmuştur. En az bu sorular kadar bu sorulara verilen cevaplar da önemlidir. Böylesine önemli bir konunun sağlıklı bir şekilde tartışılabilmesi, ancak ilmi verilerin temel kabul edilmesiyle yapılabilir. $\mathrm{Bu}$ sorulara bilimsel çerçevenin ve metodun dişında başka motivasyon unsurlarıyla hareket edilerek verilmeye çalışılan cevaplar bizi bir kısır döngüye götürebilir. Bu bilimselliğin ilk adımı Osmanlı düşünürlerinin eserlerinin incelenerek fikirlerinin anlaşılması olsa gerektir. Makalemizin genel amacı bu tartışmalara bir nebze 1şık tutmak iken özel amacı Harputlu İshak Efendi'nin din felsefesinin bazı meselelerine yaklaşımı ve filozoflara karşı tutumunun nasıl olduğunu genel hatlarıyla anlamaya çalışmaktır.

ANAHTAR KELIMELER: Harputlu İshak Efendi, Osmanlı, Felsefe, Din Felsefesi, Felsefeciler. philosophy according to the other sciences? These kinds of questions have been frequently asked by those who deal with philosophy. The answers given to these questions are as important as at least the questions. To discuss such an important subject, what we need is to accept scientific issues as basis. To answer these questions together with a different motivation which is far from scientific methods may lead us to a vicious circle. The first thing of this kind of scientific attitude is to examine the Ottoman thinkers' studies and try to understand them. General aim of this article is to shed a light to these discussions and in particular, to understand the approach of Harputlu Ishak Efendi to some issues of the philosophy of religion and his attitude towards some philosophers.

KEYWORDS: Harputlu Ishak Efendi, Ottoman, Philosophy, Philosophy of Religion, Philosophers.

\section{SUMMARY}

What were the perspectives of Ottoman thinkers or scholars towards philosophy in general and the subjects of the philosophy of religion and philosophers in particular? What was the presence and level of philosophy in Ottoman compared to other sciences? These are the questions usually asked by those who work on philosophy. The answers provided to such questions are as important as at least the questions themselves. To discuss such an important subject, what we need is to accept scientific issues as basis. Answers tried to be given with other motivation elements outside of the scientific frame and method can take us to a vicious circle. The first step of this scientific perspective should be an exam-

$$
\text { cumhuriget ilahigat dergisi 20, sy. 1 (Haziran 2016): 203-224. }
$$


Harputlu İshak Efendi'nin Din Felsefesinin Bazı Meselelerine Yaklaşımı | 205

ination of the books of Ottoman thinkers. The overall purpose of our article is to shed light on such discussions to some extent, while the specific purpose is to explain Harputlu Ishak Efendi's approach towards some matters of the philosophy of religion and his attitude towards philosophers in general terms.

When the courses, which were studied by Harputlu Ishak Efendi, and the masters, who taught these courses, are investigated, it will be seen clearly that he took a good education. Ishak Efendi, who executed important duties in different bureaucratic positions of the Ottoman such as inspection duties, then was assigned to be the judge (qâdî) of Medina and Isparta. Harputlu Ishak Efendi expressed opinions on the relationship of religion-philosophy, status of prophets and philosophers, place of the intellect in religion and especially the "Knowledge of God", "Resurrection", "Creation of the Universe" which are very controversial issues among Gazzâli and the Islamic philosophers. Providing a statement on such controversial issues requires being an expert on the Kalâm theology and philosophy. As for wording, we see that he has studied the subject with all dimensions.

Harputlu Ishak Efendi is a unique Ottoman thinker. The reason behind this is that he has never studied on annotation and elucidation, but he was a scholar paying attention to the human intellect ('aql) and use of the intellect. He expresses that he prefers using intellectual evidences as a method and this is a beneficial approach and he experienced this himself. Stating that Islam is a religion definitely based on the intellect, he expresses that "God shall not propose something contrary to the sound intellect in the religion of Islam", and claims that God does not request from human beings something contrary to the sound intellect and those requested comply with the sound intellect only. We know that some scholars educated in Ottoman Madrasas assumed took a sharp position against thoughts established and philosophy in particular. Considering the methods used by Harputlu Ishak Efendi on dealing with the issues, we see that he tries to indicate the views of other people expert on the subject while he investigates it.

cumburiget theology journal 20, no. 1 (June 2016): 203-224. 
Because the thinkers he often refers to in his works are Ibn Sina, Nasîrüddîn et-Tûsî Devvânî and Gelenbevî, we think that his philosophical thought emerges from such views. He has more references to Ibn Sina. Harputlu Ishak Efendi tried to understand what philosophers try to explain instead of declaring the philosophers as unbelievers and showing the philosophy out of religion. As some previous Ottoman scholars, he has considered the prophets as a philosopher and so tried to bring a new perspective to the discussion of religion-philosophy relation which has been continuing for centuries. Harputlu Ishak Efendi claims that the human intellect ('aql) alone can know the presence of God and His attributes such as knowledge and power. For instance, regarding the oneness of God, he puts similar views with Kindî. He also states that it is not possible both rationally and traditionally that there is an existent equal and similar with God. He provides evidences from scholars, Ibn Sina in particular. However, he stresses that there are some religious matters which cannot be known by the intellect.

Providing opinions on whether the resurrection will be bodily and spiritual or spiritual only, Harputlu Ishak Efendi gives his views on that God knows totals but partials, which is why Gazzâlî declared the Islamic philosophers as unbelievers. Harputlu Ishak Efendi also provides ideas on the eternity of the universe which has been one of the main problems between the philosophers and Gazzâlî. The matters studied by Harputlu Ishak Efendi are the main subject of the religion and majority of which corresponds to the three basic fields of philosophy: existence, knowledge, and value. As many of the previous scholars, Harputlu Ishak Efendi studied these matters through a method of question and answer. In explaining these subjects, he firstly provided verses from the Qur'an and then provided the hadiths, if any. Then he wrote down what the philosophers, Kalâm theologians, and sûfis said about the matter. And what is significant is that he did not provide any adverse remark while referencing such approaches of this group of three.

We, recently, see more often the oral statements and approaches in this regard which signify that the philosophy of religion should be built upon its own resources and thinkers in the Islamic lands. The meaning of this excitement with regards to the philosophy of religion is more mean-

$$
\text { cumhuriget ilahigat dergisi 20, sy. 1 (Haziran 2016): 203-224. }
$$


Harputlu İshak Efendi'nin Din Felsefesinin Bazı Meselelerine Yaklaşımı | 207

ingful in specific terms. The problem, as often stated by the recent philosophers of religion, that we do not still have a unique philosophy of religion model despite we owe very rich, important classic and scientific works, is still under discussion. We hope that trying to understand what Ottoman scholars and thinkers remarked on such significant matters shall contribute to the project of "developing a unique philosophy of religion to us."

\section{GİRIŞ}

Bazılarına göre, Osmanlı'da ilim adamlarının ilmi hürriyetleri var gibi gözükse de bu, dini-resmi inancın çerçevesi içinde kalındığı, kültürdeyerleşik ve alışılmış olanın dışına çıkılmadığı sürece vardır. Yeniyi arama, bulma ve ileri sürme hürriyeti Osmanlı âlimlerinde yoktu. Bunun gibi nedenlerden ötürü Osmanlı toplumunda hür düşünürler yetişmiyordu. Bu da felsefenin Osmanlı'da olmayışının en temel nedeni idi. ${ }^{1} \mathrm{Bu}$ ve benzeri düşüncelerin altında yatan temel saik Osmanlı'daki felsefi çalışmaların ortaya çıkardığı ürünlerin orijinal olmadığ f fikridir. Bir diğer sebep ise, Osmanlı bilginlerinin entelektüel birikimini aşağılamak için bu tip fikirlerin savunulmuş olma ihtimalidir. Yine böyle düşünülmesinin sebebi olarak ortaya konulan bir düşünce de, bazılarına göre felsefe denilince akla ilk gelen özellikle kıta Avrupa'sında ortaya çıkan Materyalist, Pozitivist ya da Ateist felsefenin-en azından Tanzimat sonrasına kadar ${ }^{2}$ kayda değer bir şekilde Osmanlı'da görülmeyişidir diyebiliriz.

Bu görüşlere katılmayanlara göre ise; Osmanlı düşünürleri kendilerinden önceki İslam düşüncesi geleneğini, Yunan felsefesinin esaslarını kavramış, temellük etmiş ve o geleneği bir ölçüde devam ettirmişlerdir. Onlara göre Osmanlı bilginleri Ebû Nasr Muhammed b. Muhammed b. Tarhan b. Uzluğ el-Fârâbî et-Türkî'den (ö. 339/950) başlayan ve Seyyid eş-Şerîf el-Cürcânî’ye (ö. 816/1413) kadar dayanan düşünce geleneğinin

1 Hüseyin Aydın, “Osmanlılarda Felsefi Düşünce”, Uludağ Üniversitesi Illahiyat Fakültesi Dergisi 4, sy. 4 (1992): 7.

2 Eyüp Bekiryazıcı, “Tanzimat'tan Cumhuriyet'e Osmanlı'da Felsefe Üzerine Bir Değerlendirme", Atatürk Üniversitesi İlahiyat Fakültesi Dergisi, sy. 19 (2003); Ali Yıldırım, “Günümüz Türk Toplumunda Felsefeye Yönelik Olumsuz Bakışın Tarihsel Arka Planı Üzerine Bir İnceleme", Gaziosmanpaşa Üniversitesi İlahiyat Fakültesi Dergisi, sy. 2(2013/I): 201224.

$$
\text { cumhuriget theology journal 20, no. 1 (June 2016): 203-224. }
$$


bir parçasıdırlar. Bu iki düşünür arasında İbn Sînâ (ö. 428/1037), Gazzâlî (ö. 505/1111), Sühreverdî el-Maktûl (ö. 587/1191), Fahreddîn er-Râzî (ö. 606/1210), Sa'deddîn et-Taftazânî (ö. 792/1390) gibi filozof ve düşünürler vardır. Bütün bu geleneği ve bu geleneği devam ettirenleri yok sayarak Gazzâlî́den (ö. 505/1111) sonraki dönemi bir şerh ve haşiyeler dönemi diye niteleyip küçük görmek sekiz asırlık bir fikir, ilim ve kültür geleneğini hafife almaktır ki bu da yanlış bir tutum olsa gerektir. ${ }^{3}$

Felsefenin Osmanlı'da özellikle de Fatih Sultan Mehmet zamanında kelâm ve tasavvuf kadar ağırlıklı bir disiplin olmadığı açıktır. ${ }^{4}$ Fakat o tarihlerde dahi dinî ilimlerin anlaşılması için akli ilimlerin şart olarak görüldüğü anlaşılıyor. ${ }^{5}$ Gazzâlî sonrası özellikle Fahreddin er-Râzî'nin ve Nasîrüddîn et-Tûsî'nin (ö. 672/1274) İbn Sina felsefesinin esaslarını benimseyerek kelâm alanında çalışmalar yaptıklarını ve kelâmın felsefîleşmeye başladığını görmekteyiz. Bazı Osmanlı bilginlerinin felsefenin kapsamına giren birtakım problemleri analiz ettiklerini ve bu konuda düşünceler ortaya koyduklarını biliyoruz. Örneğin İznik veya Osman Gazi Medresesinin ilk müderrisi Dâvûd-i Kayserî (ö. 751/1350) Aristo gibi Yunan filozoflarıyla Ebü'I-Berekat el-Bağdadi (ö. 547/1152) gibi İslam filozoflarını tenkit edebilecek seviyede felsefe bilgisine sahipti. ${ }^{6}$ Fusûsu'lHikem Matla'u Husûsi'l-Kelim fì Ma'an-i Fusûsi'i-Hikem Davüd-i Kayseri'nin en meşhur eseridir. Mukaddimesinde felsefi tasavvufun bütün meseleleri on iki bölüm halinde incelenmiştir. Müellifin "Mukaddimat" adını verdiği bu kısım, genellikle ayrı bir eser gibi değerlendirilip şerhin metninden ayrı olarak istinsah edilmiştir.7

Bu gibi çalışmaların, 12. yüzyıldan sonra Osmanlı' da kelâm, felsefe ve tasavvufun meselelerinin birbirine geçmiş bir şekilde çözülmeye çalı-

3 Süleyman Hayri Bolay, Osmanlılarda Düşünce Hayatı ve Felsefe, (Ankara: Akçağ Yayınla$\mathrm{r} 1,2005), 17$.

4 Ahmet Kamil Cihan, "Fâtih Dönemi Düşünce Hayatına Genel Bir Bakış", Erciyes Üniversitesi Sosyal Bilimler Enstitüsü Dergisi sy. 14, (2003/1): 126.

5 Kâtip Çelebi, Mîzânu'l-hak fì ihtiyâri'l-ehak - İslâmda Tenkid ve Tartışma Usulü, açılamalarla sâdeleştiren: Süleyman Uludağ - Mustafa Kara, (İstanbul: Marifet Yayınları, 1990), 38-39.

6 Mehmet Bayraktar, "Davüd-i Kayseri", Türkiye Diyanet Vakfı İslam Ansiklopedisi, c. 9 (Ankara: TDV Yayınları, 1994), 33.

7 Bayraktar, "Davüd-i Kayseri” 34-35. cumhuriget ilahigat dergisi 20, sy. 1 (Haziran 2016): 203-224. 
Harputlu İshak Efendi'nin Din Felsefesinin Bazı Meselelerine Yaklaşımı | 209

şılmasına zemin hazırlamış olduğunu görüyoruz. ${ }^{8}$ Alâüddîn et-Tûsî (ö. 887/1482), Hocazâde Muslihuddin Efendi (ö. 893/1488), Necmeddin Ali b. Ömer el-Kazvinî (ö. 903/1503), Kemalpaşazâde (ö. 940/1534), Karabâĝî (ö. 942/1535), el-Amasyavî Mümeyyedzade (ö. 962/1563), Nev'î (ö.1007/1599) ve Mestçizâde Abdullah Efendi (ö. 1148/1735) yazdıkları felsefe konularını içeren eserleriyle ön plana çıkan müelliflerden sadece bir kaçıdır. Yanyalı Es'ad Efendi (ö. 1143/1731), Pîrizâde Mehmed Sâhib (ö. 1162/1749) ve Yirmi Sekiz Mehmet Çelebi (ö. 1144/1732) gibi şahıslar ise felsefe ile ilgili bazı eserleri tercüme etmişlerdir. ${ }^{9}$ İşte bu uzun periyodun sonunda "Huzur Dersleri" ne* çok katılan biri olarak ve yazdığ 1 telif eserlerle ön plana çıkan son dönem Osmanlı bilginlerinden Harputlu İshak Efendi'nin bu felsefi geleneğe bir katkısının olup olmadığı önem arz etmektedir.

Harputlu İshak Efendi, Din-Felsefe ilişkisi, peygamberler ve filozofların durumu, aklın dindeki yeri ve özellikle Gazzâlî ve İslam filozofları arasında en tartışmalı konular olan "Allah'ın İlmi", "Yeniden Diriliş̧", "Âlemin Yaratılışı" gibi konular ile ilgili görüşler beyan etmiştir. Bu gibi tartışmalı konular üzerine görüş beyan etmek kelâm ilmine ve felsefeye vakıf olmayı gerektirir. Üslup olarak ise Onun, eserlerinde, konuları bütün yönleriyle ele aldıktan sonra sırf bir gurubu karalamaya çalışmadığını, hakikati ortaya koymaya çalıştığını görmekteyiz.

Her dönemde, farklı düşünen âlimler ve düşünürler, yaşadıkları dönemin genel geçer düşüncelerini savunanlar tarafından eleştirilmiştir ve bazı zorluklarla karşı karşıya kalmışlardır. İshak Efendi de bu tip sorunları yaşadığını fakat bunun, onu düşüncelerinden vazgeçirmediğini ifade eder. Ortaya koyduğu eserlere bakarsak, Onun, aksine daha bir ilim aşkı ile yoluna devam ettiğini söyleyebiliriz. O da birçok düşünür ve âlim gibi, bir milletin medeniyet inşasında en önemli unsurun ilim olduğunu

8 Kemal Sözen, “Klasik Dönem Osmanlı Bilginlerinin Felsefeye Karşı Tutumu”, Süleyman Demirel Üniversitesi İlahiyat Fakültesi Dergisi sy. 14, (2005/1): 3.

9 Sözen, "Klasik Dönem Osmanlı Bilginlerinin Felsefeye Karşı Tutumu” 20.

* Osmanlılar'da 1759'dan 1924 yılında hilâfetin kaldırılmasına kadar Ramazan ayında padişahın huzurunda yapılan tefsir dersleri. bk. Mehmet İpşirli, "Huzur Dersleri" Türkiye Diyanet Vakfi İslam Ansiklopedisi, c. 18 (Ankara: TDV Yayınları, 1998), 441. cumhuriget theology journal 20, no. 1 (June 2016): 203-224. 
ve o milletin ilim sayesinde ayakta kalabileceğini ifade eder. ${ }^{10}$ Harputlu İshak Efendi de, dine yönelik saldırılara karşı fikrî düzlemde gerek kelâm gerekse felsefe ve diğer alanlarda büyük çabalar sarf etmiş, buna karşın yaşadığı dönem itibariyle değeri çok da anlaşılamamış önemli bir ilim ve fikir adamıdır. ${ }^{11}$

\section{HARPUTLU ISSHAK EFENDI'NIN HAYATI}

1801 yılında Harput'un Perçene köyünde doğan İshak Efendi'nin babası Harput'un meşhur ilim adamlarından Abdullah Efendi'dir. ${ }^{12}$ İshak Efendi temel eğitimini Harput'ta tamamlamış ve daha sonra İstanbul'a gitmeye karar vermiştir. Fatih Camii'nde başladığı muallimliğini; Valide Mektebinde Birinci Muallim seviyesinde sürdürmüş, daha sonra Osmanlı şehzadelerinin eğitimi için sarayda açılan olan Şehzadegân okulu muallimliğine getirilmiştir. 1855 yılında ise İshak Efendi'nin Dârülmaârif hocalığı yaptığını bilmekteyiz. Osmanlı'nın değişik bürokratik mevkilerinde müfettişlik gibi görevler ifa eden İshak Efendi, daha sonra Medine ve Isparta kadılığı gibi önemli görevleri yürütmüştür. İlim hayatının yaklaşık kırk yılının böyle resmi görevler içinde geçtiğini biliyoruz. Bu süreçte onun hayatında bir ilim adamı olarak en önemli olay belki de 1853-1868 yılları arasında huzur derslerine* muhatap olarak katılması olmuştur diyebiliriz. Çünkü bu derslere muhatap olarak katılmak için belli bir ilmi

10 Harputlu İshak Hoca, "Müslümanlar Tarafından Hıristiyanlara Yöneltilen Yetmiş İki Dakik ve Çetin Soru", sad. Mehmet Alıc1, Milal ve Nihal, 3 sy. 1-2 (Aralık 2005 - Haziran 2006): 221.

11 Elanur Yılmaz, "Harputlu İshak Hoca'nın Teolojik Görüşleri" (Yüksek Lisans Tezi, Fırat Üniversitesi, 2006), V.

12 İshak Sunguroğlu, Harput Yollarında, (İstanbul: Elazı̆̆ Kültür ve Tanıtma Vakfı Yayınlar1, 1959), 125.

Tam bir ilmi serbestiyet içinde yapılan derslerde bir ayet okunarak mukarrir (Dersi Takrir eden alim) tarafından onun tefsiri yapılır, muhatapların sorularına ve itirazlarına mukarrir cevap verir, böylece ilmi bir mübahase cereyan ederdi. 11l. Selim döneminde muhatap sayısı yedi sekiz kadardı. Mukarrir ve muhataplar için gizlilik esastı. Bunlar ramazanda resmi ders günleri gelmeden özel olarak kendi aralarında ders müzakeresinde bulunamazlar, ancak günleri gelince aleni olarak ders yapabilirlerdi. Meclislerin toplantı yerini padişah belirlerdi. Burada mukarrir padişahın sağında, muhataplar ise mukarririn yanında yarım daire şeklinde önlerinde rahlelerle minderlere otururlardı. bk. Mehmet İpşirli, "Huzur Dersleri" Türkiye Diyanet Vakfı İslam Ansiklopedisi, c. 18 (Ankara: TDV Yayınları, 1998), 442-443.

$$
\text { cumhuriget ilahigat dergisi 20, sy. 1 (Haziran 2016): 203-224. }
$$


seviyede olmak gerekti. İshak Efendi 11 Nisan 1892 tarihinde vefat etmiş ve Fatih Camii haziresine defnedilmiştir. Kendisi gibi iyi yetiştirdiği oğlu Cemaleddin Molla da, Osmanlı Devleti'nde Misır'da kadılık yapan son kişidir. ${ }^{13}$

Harputlu İshak Efendi'nin tahsil ettiği ilimlere ve bu ilimleri aldığı hocalara baktığımızda Abdullah el-Harputî'den Sarf derslerini, Seyyid elHacc Ali el-Harputî'den Nahv ve Mantık derslerini, Mustafa elVedinî'den Belagat ve Usul derslerini, el-Hacc Ömer el-Akşehirli'den Tefsir derslerini, İmamzade Muhammed Esad'dan ise Kelâm, Felsefe, Hadis, Fıkıh ilmiyle beraber diğer akli ve nakli dersleri okuduğunu görmekteyiz. ${ }^{14}$

\section{ESERLERI}

Harputlu İshak Efendi'nin yedi adet telif eseri vardır. Bunun d1şında biri tercüme biri hatırat türü olmak üzere iki eseri daha vardır. Bu eserler ve içerikleri genel olarak şöyledir:

1- Es'ile ve ecvibe-i mecmuatü'l-kavaid: Genel olarak mantık konularını ele alır. ${ }^{15}$

2- Şemsü'l-hakîka: Anadolu'da faaliyet gösteren Hristiyan misyonerlerine karşı yazılan eserin sonunda Hıristiyanlığa yöneltilmiş yetmiş iki soru yer almaktadır. ${ }^{16}$

3- Kâşifü'l-esrâr dâfiü'l-eşrâr: İshak Efendi bu kitabı, Bektaşiliğin dine aykırı görüşlerini etkisiz hale getirmek için yazdığını ifade etmiş ise de eser daha çok Hurufiliğe reddiye mahiyetindedir. ${ }^{17}$

4- Miftâhu'l-uyûn: Eser, İslam düşünürlerinin genelde tartıştıkları konulardan olan Allah ve sıfatları, ruhun mahiyeti, çeşitleri ve ruh-beden ilişkisinden bahsetmektedir. ${ }^{18}$

13 Mustafa Kara, "Harputlu İshak Efendi", Türkiye Diyanet Vakfı İslam Ansiklopedisi, c. 22 (Ankara: TDV Yayınları, 2000), 531.

14 Harputlu İshak Efendi, İcazetnâme (İstanbul, ts.), 3-6.

15 Enver Demirpolat, "Huzur Derslerine Katılan Harputlu Âlimler", Fırat Üniversitesi Ilahiyat Fakültesi Dergisi XVII, sy. 4, (2012): 228.

16 Kara, "Harputlu İshak Efendi", s. 531.

17 Kara, "Harputlu İshak Efendi", s. 532.

$$
\text { cumburiget theology journal 20, no. 1 (June 2016): 203-224. }
$$


5- Es'ile ve ecvibe-i hikemiyye: İshak Efendi bu eserini insanlardaki her türlü şüpheyi gidermek için kaleme aldığını belirtmektedir. Akaid, kelâm, tasavvuf ve felsefeye dair konuların soru-cevap tarzında ele alındığ 1 kitabın yarısından itibaren bazı sorular "Karınca Kaptan" adlı bir kişinin ağzından sorulmaktadır. ${ }^{19}$

6- Diyâu'l-kulûb: Hristiyanlığa ve özellikle Protestan misyonerlere karşı kaleme alınan eserde, Kitab-1 Mukaddes'in tarihi üzerinde durulmuş, mevcut İncillerin Hz. İsa'ya verilen İncil olmadığı kanıtlanmaya çalışılmiştır.

7- el-İstişfâ fi tercemeti'ş-şif̂a: Harputlu İshak Efendi, İbn Sina'nın Şifa adlı bu eserinin İlahiyat bölümünü, Türkçe'ye çevirmiştir. ${ }^{20}$

8- Es'ile-i kelâmiyye ve zübdet-ü ilm-i kelâm: Kelâm ilminin öğrenimini ve öğretimini kolaylaştırmak amacıyla kaleme alınan bu eser aynı zamanda insanların dini konularda gaflete düşmelerinin önüne geçmek için yazılmiştır. ${ }^{21}$

9- İcâzetnâme: Harputlu İshak Efendi'nin hangi hocalardan ders aldığını belirten, ayrıca onun eğitim hayatından kesitler sunan bir eserdir. ${ }^{22}$

\section{HARPUTLU ISSHAK EFENDI'NIN DİN FELSEFESININN BAZI MESELELERINNE YAKLAŞIMI VE FELSEFECILLERE KARŞI TUTUMU}

Harputlu İshak Efendi özgün bir Osmanlı düşünürüdür. Bunu söylemimizin sebebi şerh ve haşiye türü çalışmalar yapmaması ${ }^{23}$, akla, aklı kullanmaya önem veren bir âlim olmasıdır. $\mathrm{O}$, seçtiği meseleleri açıklarken metot olarak öncelikle akli kanitlara başvurma yoluna gittiğini, bunun faydalı bir metot olduğunu ve bunu bizzat kendisinin tecrübe

Demirpolat, "Huzur Derslerine Katılan Harputlu Âlimler", 229.

19 Kara, "Harputlu İshak Efendi", s. 532; Demirpolat, "Huzur Derslerine Katılan Harputlu Âlimler", 229.

20 Kara, "Harputlu İshak Efendi", s. 532.

21 Demirpolat, "Huzur Derslerine Katılan Harputlu Âlimler", 229.

22 Demirpolat, "Huzur Derslerine Katılan Harputlu Âlimler", 229.

23 Enver Demirpolat, "Osmanl - Türk Düşünürü Harputi Hoca İshak'ın Felsefi Görüşleri", (Doktora Tezi, Selçuk Üniversitesi, 2003), 47-48.

$$
\text { cumhuriget ilahigat dergisi 20, sy. 1 (Haziran 2016): 203-224. }
$$


Harputlu İshak Efendi'nin Din Felsefesinin Bazı Meselelerine Yaklaşımı | 213

ettiğini ifade etmektedir. ${ }^{24}$ İslam dininin akla çok önem veren bir din olduğunu "Din-i İslâm'da akl-ı müstakîmin kabul etmediği şey ile Cenâb-ı Hakk teklif etmez." 25 diyerek Allah'ın akla mugayir bir şeyi insandan istemeyeceğini ve Onun insandan istediklerinin akılla, ama müstakim akılla, anlaşılabileceğini iddia eder. Kendisinin esasen meşhur olduğu mesele argümantasyon tarzını kullanarak Hıristiyan teolojisinin tutarsızlı̆ını ortaya koymak amacıyla yazdığı reddiyelerdir. Önce polemiğe konu olan iddiayı belirttiği çalışmalarında İshak Efendi, daha sonra konuyla ilgili cevabını ifade etmiştir. Bu yöntemlerle Hıristiyan teolojisini inceleme konusu yapan Harputlu İshak Efendi'nin teslis doktrinine yönelik eleştirileri epey ses getirmiştir. ${ }^{26}$

Osmanlı medreselerinde yetişmiş âlimlerin bazılarının, aykırı görüşlere özellikle de felsefeye karşı sert bir tavır takındıklarını biliyoruz. ${ }^{27}$ Harputlu İshak Efendi'nin meseleleri ele alış tarzına baktığımızda ise onun herhangi bir konuyu incelerken, değişik ilimlerden ön plana çıan kişilerin o konu hakkındaki görüşlerini vermeye çalıştığını görmekteyiz. Bunu yapmasının sebebi insanlara bir konu hakkındaki alternatif görüşleri bilme imkânı tanımak istemesidir ki bu da onun farklı düşünce ve görüşlere karşı önyargısız bir âlim olduğunu gösterir. Örneğin Allah'ın eşi ve benzeri olmasının mümkün olmadığını sadece nakille ortaya koymakla yetinmemiş bu konuda filozoflardan, İbn Sina'dan örnekler vererek bunu aklen de ispatlamaya çalışmıştır. ${ }^{28}$ Yine Allah'ın varlığının kanıtlanması konusunda daha çok İslam filozofları gibi akli kanıtları kullanmıştır ki bu da onun felsefeye ve filozoflara karşı ön yargılı olmadığı-

24 Harputlu İshak Efendi, Es'ile-i Hikemiyye, (İstanbul: Ali Şevki Efendi Matbaası, 1278), 23.

25 Emine Puse, "Harputlu İshak efendi ve Ziyâu'l-Kulûb Adlı Eseri" (Yüksek Lisans Tezi, Sakarya Üniversitesi 2010), 62.

26 İbrahim Kaplan, "Harput'lu İshak Efendi'ye Göre Teslis Doktrininin Çelişkileri” Hikmet Yurdu, Düşünce - Yorum Sosyal Bilimler Araştırma Dergisi 9, sy. 17 (Ocak - Haziran, 2016/1): 176.

27 Bk. Hatice Toksöz, “Osmanlı'nın Klasik Döneminde Felsefe ve Değeri”, Değerler Ĕ̆itimi Dergisi 5, sy. 13, (2007); Hüseyin Aydın, “Osmanlılarda Felsefi Düşünce”, Uludă̆ Üniversitesi İlahiyat Fakültesi Dergisi 4, sy. 4, (1992); Eyüp Bekiryazıc1, “Tanzimat'tan Cumhuriyet'e Osmanlı'da Felsefe Üzerine Bir Değerlendirme”, Atatürk Üniversitesi Ilahiyat Fakültesi Dergisi sy. 19 (2003).

28 Harputlu İshak Efendi, Şemsü'l-Hakika, (İstanbul, 1278), 71. cumburiget theology journal 20, no. 1 (June 2016): 203-224. 
nın bir göstergesidir. ${ }^{29}$ Peygamberliğin gerekliliği konusunda da genelde filozofların kullandığı delilleri kullanmıştır. ${ }^{30}$

O, kelâmcıların Allah'ın varlığının ispatı konusundaki delilleri ile filozofların ileri sürdüğü delillerin eş değerde ispat yolları olduğunu, kelâmcılar ile filozoflar arasında metot farkı olduğunu söyler. Örneğin, kelâmcılar sebepliden yola çıkarak sebebe varırken filozofların, İbn Sina'nın da yaptığı gibi, sebepten yola çıkarak sebepliyi açıkladıklarını söyler. Ona göre filozoflar, varlı̆̆ zorunlu ve mümkün olarak ikiye ayırarak Tanrı'nın zatına, sonra zorunlu varlık ve mümkün varlık hakkında düşünerek Tanrı'nın sıfatlarına ve sıfatlarından da Tanrı'nın fiillerinin meydana gelişinin nasıl olduğuna ulaştılar. ${ }^{31}$

Harputlu İshak Efendi de kendinden önceki Taşköprizâde Ahmed Efendi (ö. 968/1561) gibi, ${ }^{32}$ nazari hikmeti (kuramsal felsefe) üç kısma ayırır: Bunların;

Ilahiyat (Metafizik), Hikmet-i Riyaziye (Matematik) ve Hikmet-i Tabiiyye (Doğa) olduğunu söyler. Kendisi de bu ilmi yani felsefeyi hem öğrendiğini hem de öğrettiğini belirtir. ${ }^{33}$

Harputlu İshak Efendi, aklın, Allah'ın varlığını ve O'nun ilim ve kudret gibi sıfatlarını tek başına bilebileceğini söyler. Örneğin Allah'ın birliği konusunda Kindî ile benzer görüşler ortaya koyar. ${ }^{34}$ Yine Allah'ın eşi ve benzeri olmasının hem aklen hem de naklen mümkün olmadığını söyler. İbn Sina başta olmak üzere bu konuda filozoflardan deliller ileri sürer. ${ }^{35}$ Ama bunların dışında dinin akıl tarafından bilinmesinin mümkün olmadığı konuları da olduğunu belirtir. Ona göre insanlar birçok şeyin doğru mu yanlış mı olduğunu uzun yıllar yaşadıkları tecrübelerle

29 Harputlu İshak Efendi, Es'ile-i Hikemiyye, 114; Demirpolat, Osmanlı - Türk Düşünürü Harputi Hoca İshak'ın Felsefi Görüşleri, 79.

30 Harputlu İshak Efendi, Es'ile-i Hikemiyye, 14.

31 Ramazan Biçer, "Harput'lu İshak Efendi'nin Kelâmî Görüşleri”, Dünü ve Bugünüyle Harput: Tarih - Edebiyat - Şiir - Folklor, (Elazı̆̆g: Türkiye Diyanet Vakfı Elazı ̆̆ Şubesi Yayınlar1, 1999), 259.

32 Taşköprülüzâde Ahmed Efendi, Mevzuat'ül-Ulûm - İlimler Ansiklopedis), (İstanbul: Üçdal Neşriyat, 2011), 283-284.

33 Harputlu İshak Efendi, Es'ile-i Hikemiyye, 84-85.

34 Demirpolat, Osmanl - Türk Düşünürü Harputi Hoca İshak’ın Felsefi Görüşleri, 71.

35 Harputlu İshak Efendi, Şemsü'l-Hakika, 71. cumhuriget ilahigat dergisi 20, sy. 1 (Haziran 2016): 203-224. 
Harputlu İshak Efendi'nin Din Felsefesinin Bazı Meselelerine Yaklaşımı | 215

bilirler. Yine gerek Amerika gerekse Afrika'da çok önceleri yaşamış insanların akıllı olmalarına rağmen insana hiç yakışmayan bir yaşam tarzı içinde olduklarını bildiğimizi ifade eder. Bununla da aklın tek başına yeterli olmadığını ispat etmeye çalışır. ${ }^{36} \mathrm{Ki}$ bu konuda, filozoflardan Eflatun ile Aristo'nun ilmi bir araya getirilse bile ancak İbn-i Sina'nın ki kadardır, diyerek bu filozofların sadece akılları ile ulaştıkları ilmi mesafenin ancak Müslüman bir filozofun ulaştığı mesafe kadar olduğunu söyler. Bu ifadeleri ile o, vahyin akla ne kadar büyük bir yardımcı olduğunu anlatmak ister. ${ }^{37}$

Harputlu İshak Efendi, filozofları tekfir etmek ve felsefeyi din dışı görmek yerine filozofların ne söylemeye çalıştığını anlamaya çalışmıştır. Kendinden önceki bazı Osmanlı bilginleri gibi, peygamberleri filozof sayarak $^{38}$ aslında o, asırlardır devam eden felsefe-din ilişkisi tartışmasına bir bakış açısı getirmeye de çalışmıştır. $\mathrm{O}$, felsefenin peygamberler tarafından insanlara öğretildiğini filozofların Hürmüz diye isimlendirdikleri İdris Peygamberin felsefenin temel konularını insanlara öğrettiğini söyleyerek ispat etmeye çalışır. Ki ondan sonra gelen peygamberler de kendi ümmetlerine felsefenin temel konuları olarak görülen varlık, bilgi ve değer konularında, direk olmasa da dolaylı olarak yol göstermişlerdir. ${ }^{39}$ Harputlu İshak efendinin felsefeye ve felsefe tarihine vakıf olduğunu Pisagor, Eflatun'un idealar âlemi, görüşleri, felsefesi hakkında verdiği bilgilerden anlıyoruz. ${ }^{40} \mathrm{O}$, hiçbir peygamberin bir filozofa tabi olmadığını bütün filozofların bir peygambere tabi olduğunu iddia eder. Buna da Sokrates ve Eflatun gibi filozofların Benî İsrail peygamberlerine tabi olmasını, Farabi ve İbn Sina gibi filozofların ise Hz.Muhammed'e tabi olmasını örnek verir. ${ }^{41}$

36 Biçer, "Harput'lu İshak Efendi'nin Kelâmî Görüşleri”, 267.

37 Harputlu İshak Efendi, Es'ile-i Hikemiyye, 33-34.

38 Tuncay Akgün, “Taşköprülüzâde Ahmet Efendi'ye Göre Osmanlı'da Akli ve Nakli İlimler Ayrımı Bağlamında Felsefe", Uluslararası Katılımlı Osmanlı Bilim ve Düşünce Tarihi Sempozyumu, ed. M. Fatih Gökçek, (Gümüşhane: Gümüşhane Üniversitesi Yayınları, 2014), 393.

39 Harputlu İshak Efendi, Es'ile-i Hikemiyye, 4 - 5.

40 Harputlu İshak Efendi, Cevab Veremedi, (Ziyâu'l-Kulûb"un sadeleştirilmiş şekli), İstanbul: Hakîkat yayınları, 1997, 187-191.

${ }_{41}$ İshak Efendi, Es'ile-i Hikemiyye, 4,-6; 83-84. cumhuriget theology journal 20, no. I (June 2016): 203-224. 
Görülüyor ki Hz. İdris'in peygamber-filozof olarak kabul edilmesi, hem felsefenin Yunan'dan da önce olduğunun, hem de akli faaliyetleri peygamberlerin başlatmış olduğunun kabul edilmesi anlamına gelir. ${ }^{42}$ Zaten Harputlu İshak Efendi'ye göre filozoflar da peygamberlerin gönderilmesini zorunlu görmüşlerdir. Buna örnek olarak da filozofların reisi olarak gördüğü İbn Sina'nin Şifa'sında bu meseleye dair birçok delil ortaya koyduğunu söyler. ${ }^{43}$ Kısacası $\mathrm{O}$, felsefenin aslının peygamberlerin öğretilerine dayandığını, filozofların ise ayrıntıları anlattığını belirtmektedir. ${ }^{44}$

Eserlerinde sık sık görüşlerini beyan ettiği düşünürler; İbn Sina, Nasîrüddîn et-Tûsî (ö. 672/1274), Devvânî (ö. 908/1502) ve Gelenbevî (ö. 1205/1791) olduğu için felsefi görüşlerinin bu düşünürler çizgisinde ortaya çıktığını düşünmekteyiz. ${ }^{45} \mathrm{O}$ İbn Sina'ya ise daha çok atıfta bulunur. ${ }^{46}$ Yukarıda eserlerinden bahsederken İbn Sina'nın Şifa adlı eserinin ilahiyat adlı bölümünün İshak Efendi tarafından "el-İstişfa fi-tercemeti'ş-şifa" adıyla Türkçe' ye çevrildiğini belirtmiştik.

Ölümden sonraki hayatta dirilişin cismani ve ruhani mi yoksa sadece ruhani mi olacağı tartışmasına da değinen Harputlu İshak Efendi, filozoflardan Sokrates, Eflatun ve Aristo gibilerinin haşrın sadece ruhani olacağını söylediklerini belirtir. Bu filozoflara göre asıl cevher ruhtur. ${ }^{47}$ İslam filozoflarının büyük bir kısmı da kelâmcıların pek çoğundan farklı olarak, ruhun bedenden bağımsız, "kendi başına kaim bir cevher" olduğu görüşünü savunmuşlardır. Ruhun ölümsüzlügü konusunda en ciddi şekilde duran filozofların başında Farabi ve İbn Sina gelir. İbn Sina'ya göre düşünen nefis, basit, kendi başına var olan bir şey olduğu için bedenin ölmesiyle ölmez. İbn Sina'ya göre o bizatihi ölümsüzdür. Düşünen nefis, bedenin ölümünden sonra sonsuzca yaşamaya devam eder. Gerek Farabi, gerekse İbn Sina, ölümsüzlüğü, düşünen nefse hasretmektedirler.

42 Bolay, Osmanlılarda Düşünce Hayatı ve Felsefe, 47.

43 Harputlu İshak Efendi, Es'ile-i Hikemiyye, 14.

44 Harputlu İshak Efendi, Es'ile-i Hikemiyye, 11-13.

45 Harputlu İshak Efendi, Es'ile-i Kelâmiyye ve Zübdet-ü İlm-i Kelâm, (İstanbul: Cemiyet-i İmiye-i Osmaniye Matbaası, 1866), 61-74.

46 Enver Demirpolat, "Harputlu İshak Hoca'nın Hayatı ve Eserleri”, Selçuk Üniversitesi Sosyal Bilimler Enstitüsü Dergisi sy. 9, (2003): 404.

47 Harputlu İshak Efendi, Es'ile-i Kelâmiyye ve Zübdetü'l- İlmi Kelâm, 132-135. cumhuriget ilahigat dergisi 20, sy. 1 (Haziran 2016): 203-224. 
Harputlu İshak Efendi'nin Din Felsefesinin Bazı Meselelerine Yaklaşımı | 217

Her ikisi de ahiretteki azabı ve mükâfatı (acıyı ve hazzı) ruhani nitelikte görmekte ve Kur'an'ın cennet ve cehennemle ilgili tasvirlerini sembolik manada anlamaktadırlar. ${ }^{48}$ Gazzâlî̀'yi en çok rahatsız eden de onların bu düşünceleridir. $\mathrm{O}$ bu görüşlerinden dolayı Meşşai filozofların dinden çıkmış olduklarını belirtmişti. Filozofların çoğu ile Gazzâlî, Ebul'1-Kasım Ragıp el-İsfehani, Fahreddin er-Râzî ve sufilerin birçoğuna göre insanın hakikati cismani olmayıp, bedende tasarruf yapan bir mücerred cevherdir ki ona nefs-i nâtıka, akıl ve ulvi ruh isimleri verilmektedir. Harputlu İshak Efendi kendisinin de bu görüşte olduğunu belirtmiştir. Ona göre nefsi natıkanın bedeni terk etmesinden sonra yeniden yuvasına dönmesi, aklın uzak göreceği bir husus değildir. Aklın kabulde zorlanması gereken, nefs-i natıkanın ilk defa beden ile nasıl bağlantı kurduğudur. ${ }^{49} \mathrm{Ki}$ ona göre zaten akıl kendi başına ahiret ahvalini kavrayamaz. ${ }^{50}$

Harputlu İshak Efendi, filozofların yeniden dirilmeyi inkâr etmedikleri fakat yukarıda ifade ettiğimiz gibi bunun mahiyetiyle ilgili farklı görüş beyan ettikleri üzerinde durur. Ehli Sünnetin ortak görüşü ise yeniden dirilmenin hem ruhen hem bedenen olduğudur. ${ }^{51} \mathrm{O}$, Kendisinin de bu görüşte olduğunu ve Kur'an'da da bu görüşü destekleyen ayetler bulunduğunu belirtir. Ona göre Allah, kişiyi, ölümünden sonra baki olan mücerred nefsi yarattığ 1 bedene iade edecektir. Bu bedenin, dünyadaki bedenle aynı olup olmayacağ açısından burada üzerinde durmamız gereken önemli husus, Harputlu İshak Efendi'nin, bütün bu düşüncelerine rağmen filozofları küfürle itham etmeyi gerektirecek bir durum olmadığını belirtmesidir. ${ }^{53}$

Harputlu İshak Efendi, Gazzâlî̀nin İslam filozoflarını tekfir ettiği diğer bir konu olan Allah'ın küllileri bilmesi ve cüzileri bilmemesi konusunda da fikir beyan eder. O bu konuda Nasîrüddîn et-Tûsî ve Devvânî gibi filozofların düşüncelerini aktarır. Nasîrüddîn Tusi'ye göre Allah eşyanın küllisini en yüce akletmeyle bilir yani bizim için duyular ve mü-

48 Muhsin Akbaş, “Ölüm ve Ölümsüzlük”, Din Felsefesi, ed. Recep Kılıç vd., (Ankara: Grafiker Yayınları, 2014), 327-328.

49 Biçer, "Harput'lu İshak Efendi'nin Kelâmî Görüşleri”, 265.

50 Biçer, "Harput'lu İshak Efendi'nin Kelâmî Görüşleri”, 267.

51 Harputlu İshak Efendi, Esile-i Hikemiyye, 120.

52 Harputlu İshak Efendi, Esile-i Hikemiyye, 125-126.

53 Harputlu İshak Efendi, Es'ile-i Kelâmiyye ve Zübdetü'l- İlmi Kelâm, 60-61. cumhuriget theology journal 20, no. I (June 2016): 203-224. 
cerred akıl sebebiyle hâsıl olan ilme $\mathrm{O}$, bizim ulaştığımız şekilde ulaşmaz. Allah'ın eşyanın hakikatini nasıl bileceğini anlattıktan sonra Harputlu İshak Efendi Allah'ın cüzileri bilemeyeceğini iddia eden filozoflar hakkında küfür lazım gelip gelmeyeceğini sorar. Sorduğu soruya verdiği cevapta, "Devvânî'ye göre küfür lazım gelmez", dedikten sonra kendi görüşlerini açıklar. Ona göre en nihayetinde filozoflar bile Allah'ın ilminden hiçbir şeyin gizli kalmayacağını kabul ederler. ${ }^{54}$ Gerek Ehl-i İslâm gerekse filozoflar Allah'ın geçmiş ve gelecek her şeyi bildiğini kabul ederler. Gerek vacip olsun gerek madum, gerek mümkün, gerek mümteni, gerekse mevcud olsun Allah'ın ilminden bir zerre miktar şey hariç değildir. ${ }^{55}$ En nihayetinde tüm bunlardan dolayı filozoflara (bu konudaki görüşlerinden dolayı) küfr lazım gelmeyeceğini ifade eder. ${ }^{56}$

Harputlu İshak efendi filozoflarla Gazzâlî arasındaki temel polemik konularından bir diğeri olan âlemin ezeliliğine dair de görüş beyan eder. Harputlu İshak Efendi'nin bu konudaki görüşleri meseleye ne kadar vakıf olduğunu gösterir niteliktedir. Bilindiği üzere Gazzâlî İslam filozoflarını âlemin ezeliliğini savundukları için tekfir etmişti. Gazzâlî'nin âlemin ezeli olup olmadığı konusunda filozoflarla bu kadar mücadele etmesinin nedeni, eğer Allah'tan başka ezeli bir varlık fikri kabul edilirse, dinin sınırlarının ötesine çıkılacağı endişesidir. Çünkü kelâmcılara göre Allah sıfatları ile bilinen bir varlıktır. Bu sıfatlardan biri de Allah'ın yarattıklarına benzememesi (muhalefetü'n li'lhavâdis) dir. Ezelilik düşüncesinin anlamı Gazzâlî̀ye göre Allah'taki bir sıfatın aynı şekilde başka bir varlığa verilmesidir. Gazzâlı̀'nin İslam filozoflarının Allah'ın varlığını ispat sadedinde ileri sürdükleri Kozmolojik delillerden biri olan 'İmkân Delili'ne itibar etmeyişinin sebebi budur. Onun 'Hudus' delili üzerinde ısrarla durmasının sebebi âlemin sonradan (zamanda) yaratıldığını vurgulamak ve açığa çıkarmaktır. Gazzâlî́n nin ezelilik konusunda hassasiyetle durmasının ikinci sebebi ise âlemin ezeliliği düşüncesinin Allah'ın özgür iradesi ile fiilini yerine getiren bir varlık olmaktan çıkıp, yaratmaya mecbur bir varlık olarak algılanması sonucunu doğurma ihtimalidir. Gazzâlî́yi âlemin ezeli olmasını redde götüren bir diğer neden de, âlemin ezeli olması fikrinin, kaynağını dinden alan "mebde" düşüncesiyle ve

\footnotetext{
Harputlu İshak Efendi, Es'ile-i Kelâmiyye ve Zübdetü'l- İlmi Kelâm, 61.

Harputlu İshak Efendi, Diyâu'l-Kulûb, (İstanbul, ts.), 367.

Harputlu İshak Efendi, Es'íle-i Kelâmiyye ve Zübdetü'l- İlmi Kelâm, 62-64. cumhuriget ilahigat dergisi 20, sy. 1 (Haziran 2016): 203-224.
} 
Harputlu İshak Efendi'nin Din Felsefesinin Bazı Meselelerine Yaklaşımı | 219

ebedi olması da yok oluşun âlem üzerine arız olmasının bir gereği olan "mead" (yeniden diriliş) düşüncesi ile çelişiyor olmasıdır. İbn Rüşd (ö. 595/1198) ise Gazzâlî’ye verdiği cevapta âlemin ezeli olduğunu açlk bir şekilde söyler fakat aynı zamanda o, problemi çözebilmek için her iki tarafı da rahatsız etmeyeceğini düşündüğü bir görüş ortaya koyar. Allah'ın ezeliliği ile âlemin ezeliliği arasında önemli bir fark görür. İki tür ezelilikten bahseder: Nedenli ezelilik ve nedensiz ezelilik. İbn Rüşd'e göre, Allah nedensiz ezeli iken âlem nedenli ezeli olmaktadır. Yani âlem Allah'ın ezeli fiili olarak, Allah tarafından nedenlenmiş (yaratılmış) ezelidir. Allah'ın âleme önceliği zamana referansla meydana gelen bir öncelik değildir. Allah'ın âleme olan önceliği ancak O'nun varlığının tamamıyla âlemin nedeni olması anlamındadır. ${ }^{57}$

Harputlu İshak Efendi, kelâmcıların hudus-i âleme felsefecilerin ise kıdem-i âleme inandıklarını belirtir. Buna göre; filozoflar maddedeki şekiller tek tek hadis olsa da nevi ve cins itibariyle ezelidir, hadis değildir. Filozoflar da Allah'tan başka her şeyi hadis olarak kabul ettiklerini, ancak onların kabul ettikleri "hudus" ile bir şeyin başka bir şeye muhtaç olması olarak tanımladıklarını kaydeder. ${ }^{58}$ O filozofların Allah'tan başka her şeyi hadis olarak kabul ettiklerini, ancak onların kabul ettikleri hudusun bir şeyin bir şey olmadan ortaya çıkamaması anlamında olduğunu, zamansal bir hudus olmadığını ifade eder. Filozoflara göre âlem ortaya çıkmak için Allah'a muhtaç idi. Allah olmasaydı âlem de olmaz idi. ${ }^{59}$ Harputlu İshak Efendi bu konudaki tespitleriyle de böylesine meşakkatli bir konuyu ne kadar iyi anladığını bize gösterir. Bu konuda meseleyi Gazzâlî gibi anlayıp İslam filozoflarını tekfir etmek yerine meseleyi İbn Rüşd ile neredeyse aynı açıdan değerlendirmiştir.

\section{SONUÇ}

Görüldügü üzere Harputlu İshak Efendi'nin tartıştığı konular dinin esas konularıdır ki bunların çoğu felsefenin üç temel alanı olan varlık, bilgi ve değere tekabül eder. Kendinden önceki pek çok ilim adamı ve

57 Geniş bilgi için bkz. Tuncay Akgün, Gazali ve İbn Rüşd'e Göre Yaratma, (Ankara: Akçağ Yayınları, 2013).

58 Yılmaz, "Harputlu İshak Hoca'nın Teolojik Görüşleri", 50-51.

59 Harputlu İshak Efendi, Es'ile-i Kelâmiyye ve Zübdetü'l- İlmi Kelâm, 8-9. cumhuriget theology journal 20, no. I (June 2016): 203-224. 
filozof gibi Harputlu İshak Efendi de bu konuları eserlerinde soru - cevap şeklinde incelemiştir. Bu konuları açıklarken metot olarak önce Kur'an'dan ayetler vermiş sonra bu konularda varsa hadisleri beyan etmiştir. Ardından bu konularda filozoflar, kelâmcılar ve mutasavviflar neler söylemiş bunları yazmıştır. Ve dikkate değer olan şu ki son üç gurubun bu konulardaki görüşlerini verirken herhangi bir olumsuz tenkitte bulunmamıştır. Kelâm ilmi ile ilgili eserleri daha çok ön planda olan Haputlu İshak Efendi'nin sık sık filozofların görüşlerinden bahsetmesi, hem nakillerinden hem de yorumlarından kelâm ilmine olduğu gibi felsefeye de ne kadar vâkıf olduğunu göstermektedir.

Harputlu İshak Efendi'nin felsefe, kelâm ve tasavvuf arasında uzlaşmacı bir tavırdan yana olduğu görülüyor. $\mathrm{O}$, birçok konunun bu ilimler arasında ortak olduğunun da, bu konulara geniş bir perspektif ile bakabilme noktasında filozofların görüşlerinin sağlayacağı katkının da farkındadır. Hatta onunla ilgili çalışma yapanlardan bazılarının, Harputlu İshak Efendinin Osmanlı'da neredeyse artık çok az ilgi ve itibar gören felsefenin yeniden ihyasına katkıda bulunmaya yönelik bir çaba içinde olduğunu iddia edenler bile olmuştur. ${ }^{60}$ Yine bu meselelerde hem kelâmcıların hem de filozofların görüşlerini belirtmesinden de anlaşılıyor ki onun amacı, felsefe ve dinin önemli bazı konularda birbirinden çok farklı şeyler söylemediklerini ortaya koymaktır.

Harputlu İshak Efendi'nin yukarıda bahsettiğimiz bazı konulardaki uzlaşmacı tavrı bize İbn Rüşd'ü hatırlatır. Onun, haşrın keyfiyeti, Allah'ın ilmi, âlemin ezeliliği gibi konularda İslam filozoflarının tekfir edilemeyeceğini söylemesi, sahip olduğu ufku gösteren en önemli kanitlardır. Şurası da muhakkak ki ele aldığı birçok konuda filozofların görüşlerinden de bahsetmesi yine felsefeye olan vukufiyetini gösterir. Ve yine bu konuların çoğunda onları görüşlerinden dolayı dini açıdan eleştirmeyişi hatta Gazzâlî gibi onların dinden çıktığını iddia edenlerin hilafına görüş beyan etmesi onun sahip olduğu zihni durumu ve yaşadığı dönemi de dikkate alırsak sahip olduğu özgüveni ve eleştirel bir akla sahip olduğunu ortaya koymaktadır.

60 Demirpolat, Osmanlı - Türk Düşünürü Harputi Hoca İshak'ın Felsefi Görüşleri, 129.

$$
\text { cumhuriget ilahigat dergisi 20, sy. 1 (Haziran 2016): 203-224. }
$$


Harputlu İshak Efendi'nin Din Felsefesinin Bazı Meselelerine Yaklaşımı | 221

Harputlu İshak Efendi gibi son dönem bir Osmanlı düşünürünün/bilgininin böyle bir perspektife sahip olması, makalemizin giriş bölümünde ifade etmeye çalıştı̆̆ımız Osmanlı düşünürleri/bilginleri ile ilgili sahip olunan paradigmayı tekrar gözden geçirmemiz gerektiğini ortaya koyması açısından önemlidir. Bir Osmanlı düşünürünün/bilgininin bu meseleleri klasik bakış açısının dışında bir bakış açısıyla değerlendirmeye çalışması heyecan uyandıran bir durum olsa gerek. Din Felsefesinin İslam coğrafyasında kendi kaynakları ve düşünürleri üzerinden inşa edilmesi gerektiğini ifade eden gerek yazılı gerekse sözlü ifadelere ve bu minvalde ortaya çıkan teşebbüslere son dönemde daha sık rastlanmaktadır. Bu heyecanın din felsefesi alanı açısından özelde ortaya çıkan anlamı ise daha da manidardır. Özellikle son dönem din felsefecilerinin daha sık dile getirmeye başladıkları çok zengin, önemli klasik ve bilimsel kaynak eserlere sahip olmamıza rağmen kendimize özgü bir din felsefesi modeli oluşturamayışımız problemi ${ }^{61}$ hala önümüzde durmaktadır. Osmanlı bilginlerinin ve düşünürlerinin böylesine önemli konularla ilgili ne söylediklerini anlamaya çalışmanın "kendimize özgü bir din felsefesi modeli geliştirme" projesine katkı sağlayacağ 1 umudunu taşımaktayız.

Son dönem Osmanlı âlimleri ve düşünürlerinin fikirlerinin ve eserlerinin nispeten hala yeterince aydınlatılmadığı dile getirilmektedir. Bugünün araştırmacıları Tanzimat sonrası dönemin önde gelen âlimlerinin ve düşünürlerinin düşünce mirasını gün 1şığına çıkarma çabaları içindedirler. Bu çabalar son on - on beş yıl içerisinde ciddi bir hız kazandıysa da hala bunun yeterli olmadığını düşünenler de vardır. ${ }^{62}$ Bu gibi çalışmaların artmasının Türk düşünce tarihini anlamaya önemli katkılar sunaca$\breve{g}_{1}$ ise genel kabul göre bir düşüncedir. Ayrıca Harputlu İshak Efendi gibi

61 Metin Yasa, Bütüncül ve Eleştirel Din Felsefesi, Ankara: Elis Yayınları, 2013; Ahmet T. Karamustafa, "Yeni Bir Din Felsefesi Arayışı ve Elmalılı Hamdi Yazır", Osmanlı Devleti'nde Din ve Vicdan Hürriyeti, ed. Azmi Özcan, (İstanbul: Ensar Neşriyat. 2000); Recep Kılıç "Hamdi Yazır'da Din Felsefesi", Elmalıl Muhammed Hamdi Yazır Sempozyumu, 4-6 Eylül 1991, (Ankara: Türkiye Diyanet Vakfı, 1993); Bayram Dalkılıç, "Sadreddin Konevî Vasiyetnâmesi'nin Din Felsefesi Problemleri Açısından Değerlendirilmesi", Makâlât, sy. 2, 1999.

62 Ahmet T. Karamustafa, "Yeni Bir Din Felsefesi Arayışı ve Elmalılı Hamdi Yazır", Osmanlı Devleti'nde Din ve Vicdan Hürriyeti, ed. Azmi Özcan, (İstanbul: Ensar Neşriyat. 2000), 289.

$$
\text { cumhuriget theology journal 20, no. 1 (June 2016): 203-224. }
$$


önemli şahsiyetlerin felsefeye ve filozoflara karşı yukarıda ortaya koyduğumuz tavrı genelde İslam toplumu özelde ise Türk toplumunun genelinin felsefeye ve filozoflara karşı olan menfi tavrını bir nebze olsun kırmada etkili olacaktır. Böylece Müslüman toplum felsefeye ve filozoflara sadece bir bakış açısının çizdiği ufukla bakmayacak alternatif bakış açlarının felsefeye ve filozoflara bakışını da öğrenmiş olacaktır.

\section{KAYNAKÇA}

Ahmed Efendi, Taşköprülüzâde. Mevzuat'ül-Ulûm (Illimler Ansiklopedisi). İstanbul: Üçdal Neşriyat, 2011. 2 cilt.

Akbaş, Muhsin. "Ölüm ve Ölümsüzlük”, Din Felsefesi içinde, ed. Recep Kıllı̧ vd. Ankara: Grafiker Yayınları, 2014.

Akgün, Tuncay. Gazali ve İbn Rüşd'e Göre Yaratma. Ankara: Akçă̆ Yayınları, 2013. Akgün, Tuncay. "Taşköprülüzâde Ahmet Efendi'ye Göre Osmanlı'da Akli ve Nakli İlimler Ayrımı Bağlamında Felsefe", Ululslarası Katılımlı Osmanlı Bilim ve Düşünce Tarihi Sempozyumu, ed. M. Fatih Gökçek. Gümüşhane: Gümüşhane Üniversitesi Yayınları, (2014): 389-399.

Aydın, Hüseyin. "Osmanlılarda Felsefi Düşünce". Uludă̆ Üniversitesi Illahiyat Fakültesi Dergisi 4, sy. 4 (1992): 1-8.

Bayraktar, Mehmet. "Davüd-i Kayseri". Türkiye Diyanet Vakfi İslam Ansiklopedisi. 9:32-35. Ankara: TDV Yayınları, 1994.

Bekiryazıcı, Eyüp. “Tanzimat'tan Cumhuriyete Osmanlı'da Felsefe Üzerine Bir Değerlendirme". Atatürk Üniversitesi Illahiyat Fakültesi Dergisi sy. 19 (2003): 249-278.

Biçer, Ramazan. "Harput'lu İshak Efendi'nin Kelâmî Görüşleri”. Dünü ve Bugünüyle Harput: Tarih - Edebiyat - Şiir - Folklor, (24-27 Eylül 1998), Türkiye Diyanet Vakfı Elazığ Şubesi Yayınları. 1999, 2 cilt, 256-268.

Bolay, Süleyman Hayri. Osmanlılarda Düşünce Hayatı ve Felsefe. Ankara: Akçağ Yayınları, 2005.

Cihan, Ahmet Kamil. "Fâtih Dönemi Düşünce Hayatına Genel Bir Bakış". Erciyes Üniversitesi Sosyal Bilimler Enstitüsü Dergisi sy. 14, (2003/1): 119-129.

Dalkılıç, Bayram. “Sadreddin Konevî Vasiyetnâmesi'nin Din Felsefesi Problemleri Açısından Değerlendirilmesi". Makâlât, sy. 2, (1999): 157-168.

Demirpolat, Enver. "Huzur Derslerine Katılan Harputlu Âlimler". Fırat Üniversitesi Illahiyat Fakültesi Dergisi XVII, sy. 4, (2012): 213-237.

Demirpolat, Enver. “Osmanlı - Türk Düşünürü Harputi Hoca İshak'ın Felsefi Görüşleri". Doktora Tezi, Selçuk Üniversitesi, 2003.

Demirpolat, Enver. "Osmanlılarda Felsefenin Serüveni”. Firat Üniversitesi IIlahiyat Fakültesi Dergisi 14, sy. 1 (2009): 105-118.

$$
\text { cumhuriget ilahigat dergisi 20, sy. 1 (Haziran 2016): 203-224. }
$$


Harputlu İshak Efendi'nin Din Felsefesinin Bazı Meselelerine Yaklaşımı | 223

Demirpolat, Enver. "Harputlu İshak Hoca'nın Hayatı ve Eserleri”. Selçuk Üniversitesi Sosyal Bilimler Enstitüsü Dergisi sy. 9, (2003): 397-412.

İshak Efendi, Harputlu. Es'ile-i Hikemiyye. İstanbul: Ali Şevki Efendi Matbaası, 1278.

İshak Efendi, Harputlu. Şemsü'l-Hakika. İstanbul, 1278.

İshak Efendi, Harputlu. Es'ile-i Kelâmiyye ve Zübdet-ü İlm-i Kelâm. İstanbul: Cemiyet-i İlmiye-i Osmaniye Matbaası, 1866.

İshak Efendi, Harputlu. Diyâu'l-Kulûb. İstanbul, ts.

İshak Efendi, Harputlu. İcazetnâme, İstanbul, ts.

İshak Efendi, Harputlu. Cevab Veremedi. (Ziyâu'l-Kulûb"un sadeleştirilmiş şekli), İstanbul: Hakîkat yayınları, 1997.

İshak Efendi, Harputlu. “Müslümanlar Tarafından Hıristiyanlara Yöneltilen Yetmiş İki Dakik ve Çetin Soru". sadeleştiren Mehmet Alıcı, Milal ve Nihal, yıl 3 sayı 1-2 (Aralık 2005 - Haziran 2006) 221-252.

İpşirli, Mehmet. "Huzur Dersleri”. Türkiye Diyanet Vakfi İslam Ansiklopedisi. 18: 441-444. Ankara: TDV Yayınları, 1998.

Kaplan, İbrahim. "Harput'lu İshak Efendi'ye Göre Teslis Doktrininin Çelişkileri”. Hikmet Yurdu, Düşünce - Yorum Sosyal Bilimler Araştırma Dergisi 9, sy. 17, (Ocak - Haziran, 2016/1): 176-192.

Kara, Mustafa. "Harputlu İshak Efendi". Türkiye Diyanet Vakfi İslam Ansiklopedisi. 22: 531-532. Ankara: TDV Yayınları, 2000.

Karamustafa, Ahmet T. "Yeni Bir Din Felsefesi Arayışı ve Elmalılı Hamdi Yazır”. Osmanl Devleti'nde Din ve Vicdan Hürriyeti, ed. Azmi Özcan, (İstanbul: Ensar Neşriyat. 2000)

Kâtip Çelebi. Mîzânu'l-hak fî ihtiyâri'l-ehak - İslâmda Tenkid ve Tartışma Usulü. (Açıklamalarla sâdeleştiren: Süleyman Uludağ - Mustafa Kara), İstanbul: Marifet Yayınları, 1990.

Kılıç, Recep. “Hamdi Yazır'da Din Felsefesi”. Elmalılı Muhammed Hamdi Yazır Sempozyumu, 4-6 Eylül 1991, Ankara: Türkiye Diyanet Vakfı, (1993): 290298.

Puse, Emine. "Harputlu İshak Efendi ve Ziyâu'l-Kulûb Adlı Eseri". Yüksek Lisans Tezi, Sakarya Üniversitesi, 2010.

Sözen, Kemal. "Klasik Dönem Osmanlı Bilginlerinin Felsefeye Karşı Tutumu". Süleyman Demirel Üniversitesi İlahiyat Fakültesi Dergisi sy. 14, (2005/1): 1-23.

Sunguroğlu, İshak. Harput Yollarında. İstanbul: Elazığ Kültür ve Tanıtma Vakfı Yayınları, 2 cilt, 1959.

Toksöz, Hatice. “Osmanlı'nın Klasik Döneminde Felsefe ve Değeri”. Değerler Ĕ̆itimi Dergisi 5, sy. 13 (2007): 123-154.

Yasa, Metin. Bütüncül ve Eleştirel Din Felsefesi. Ankara: Elis Yayınları, 2013. 
Yıldırım, Ali. “Günümüz Türk Toplumunda Felsefeye Yönelik Olumsuz Bakışın Tarihsel Arka Planı Üzerine Bir İnceleme”. Gaziosmanpaşa Üniversitesi İlahiyat Fakültesi Dergisi sy. 2 (2013/I): 201-224.

Yılmaz, Elanur. "Harputlu İshak Hoca'nın Teolojik Görüşleri”. Yüksek Lisans Tezi, Firat Üniversitesi, 2006.

cumhuriget ilahigat dergisi 20, sy. 1 (Haziran 2016): 203-224. 